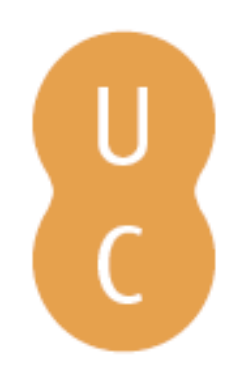

\title{
nombalina
}

\section{A união de facto e a lei civil no ensino de Francisco Manuel Pereira Coelho e na legislação atual}

\author{
Autor(es): $\quad$ Xavier, Rita Lobo \\ Publicado por: Imprensa da Universidade de Coimbra \\ URL \\ persistente: URI:http://hdl.handle.net/10316.2/38897 \\ DOI: $\quad$ DOI:http://dx.doi.org/10.14195/978-989-26-1113-6_19 \\ Accessed : $\quad$ 26-Apr-2023 15:14:00
}

A navegação consulta e descarregamento dos títulos inseridos nas Bibliotecas Digitais UC Digitalis, UC Pombalina e UC Impactum, pressupõem a aceitação plena e sem reservas dos Termos e Condições de Uso destas Bibliotecas Digitais, disponíveis em https://digitalis.uc.pt/pt-pt/termos.

Conforme exposto nos referidos Termos e Condições de Uso, o descarregamento de títulos de acesso restrito requer uma licença válida de autorização devendo o utilizador aceder ao(s) documento(s) a partir de um endereço de IP da instituição detentora da supramencionada licença.

Ao utilizador é apenas permitido o descarregamento para uso pessoal, pelo que o emprego do(s) título(s) descarregado(s) para outro fim, designadamente comercial, carece de autorização do respetivo autor ou editor da obra.

Na medida em que todas as obras da UC Digitalis se encontram protegidas pelo Código do Direito de Autor e Direitos Conexos e demais legislação aplicável, toda a cópia, parcial ou total, deste documento, nos casos em que é legalmente admitida, deverá conter ou fazer-se acompanhar por este aviso.

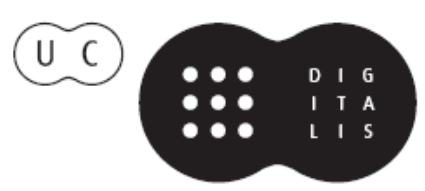




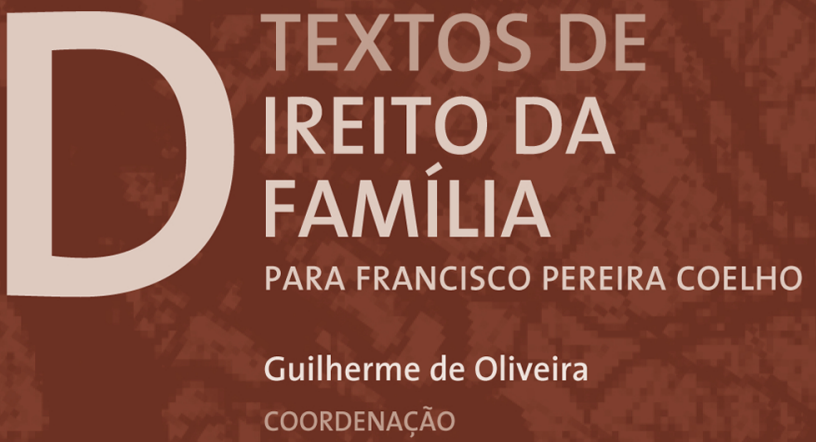




\section{A UNIÃO DE FACTO E A LEI CIVIL NO ENSINO DE FRANCISCO MANUEL PEREIRA COELHO E NA LEGISLAÇ ÃO ATUAL ${ }^{1}$}

Rita Lobo Xavier

Professora Associada da Faculdade de Direito da Universidade Católica Portuguesa-Porto

\section{Sumário}

Introdução; 1. A união de facto no ensino de Francisco Manuel Pereira Coelho; 1.1 A consagração do termo "união de facto" pela Reforma de 1977; 1.2 A união de facto e a Constituição da República Portuguesa de 1976; 1.3 A inventariação dos efeitos reconhecidos pela lei à união de facto e a natureza jurídica desta; 1.4 A "institucionalização" da união de facto; $1.5 \mathrm{~A}$ noção de união de facto; 1.6 A prova da união de facto; $1.7 \mathrm{O}$ destino da casa de morada comum no caso de dissolução da relação; 1.8 A cessação da pensão de alimentos devida por ex-cônjuge; 1.9 Os efeitos patrimoniais entre os membros da união de facto; 1.10 O direito a indemnização no caso de lesão de que proveio a morte de um dos membros da união de facto; 1.11 A reparação dos prejuízos causados em caso de injusta ruptura da união de facto; 1.12 Conclusões; 2 . A união de facto na legislação atual; 2.1. A noção de união de facto; 2.2. A prova da união de facto; 2.3. O reconhecimento de uma forma de "economia doméstica" comum.

\footnotetext{
${ }^{1}$ Nota do Coordenador: o texto foi escrito antes da aprovação, pela Assembleia da República, da adoção por casais do mesmo sexo.
} 


\section{Introdução}

Os escritos de PEREIRA COELHO sobre a união de facto começaram por ter como referência a comunhão de vida sem casamento, pressupondo a convivência entre um homem e uma mulher "em condições análogas às dos cônjuges", isto é, adotando a mesma residência e comportamentos semelhantes aos das pessoas casadas. Na verdade, era esta a situação abrangida pela designação união de facto na lei civil portuguesa, desde a sua consagraçâo terminológica na norma do artigo $2020 .^{\circ}$ do Código Civil (CC), no contexto da chamada Reforma de 1977, até à Lei n. ${ }^{\circ}$ 7/2001, de 11 de maio (Lei das Uniões de Facto - LUF), que passou a referir-se à situação "de duas pessoas, independentemente do sexo, que vivam em união de facto" (artigo 1. $.^{\circ},{ }^{\circ}{ }^{\circ} 1$ ).

As páginas de PEREIRA COELHO sobre a união de facto foram acompanhando as alterações legislativas. Em Casamento e família no direito português (1986), dedicou-se ao regime da união de facto na perspetiva constitucional, discordando quer da interpretação do artigo 36. ${ }^{\circ}$, n. ${ }^{\circ}$ 1, da Constituição da República Portuguesa de 1976 (CRP) sustentada por CASTRO MENDES, quer da defendida por GOMES CANOTILHO e VITAL MOREIRA, e propondo uma leitura do referido preceito que viria a consolidar até à mais recente edição do Curso de Direito da Família, em 2008². Nesse texto, também procedeu à inventariação dos efeitos então concedidos pela lei civil à união de facto. Na Revista de Legislação e de Jurisprudência, ficou registada a sua anotação à primeira pronúncia do Supremo Tribunal de Justiça sobre a aplicação do artigo $2020 .^{\circ}$ do CC, nove anos volvidos sobre a sua aprovação pelo Decreto-Lei n. ${ }^{\circ} 496 / 77$, de 25 de novembro. Nas

2 Coelho, Francisco Manuel Pereira e Oliveira, Guilherme de (2008). MEndes, João de Castro (1977), p. 372. CANOTILHO, Joaquim Gomes e MOREIRA, Vital (2007), p. 561. 
versões policopiadas do Curso de Direito da Família, a menção à união de facto centrou-se na descrição dos seus efeitos legais, agrupados em efeitos desfavoráveis e efeitos favoráveis aos membros da união de facto. Nas versões de 1981 e de 1986, o elenco dos efeitos ocupa uma nota de rodapé, em mais de duas páginas ${ }^{3}$.

A partir da $2^{\text {a }}$ Edição impressa, o Volume I do Curso de Direito da Família - Direito Matrimonial, já em co-autoria com GuILHERME DE OLIVEIRA, contém um capítulo autónomo sobre relações parafamiliares, com uma divisão mais desenvolvida relativa à união de facto $^{4}$. No prefácio a esta edição, PEREIRA COELHO identifica as contribuições de GUILHERME DE Oliveira e de RUI MOURA RAMOS. Por exclusão de partes, será legítimo concluir que os textos relativos à união de facto são da sua principal responsabilidade. Nas edições subsequentes, as notas introdutórias mantêm a referência àquela distribuição, sendo mencionada, na nota à $4^{a}$ edição, a ajuda de NUNO DE SALTER CID ("na parte que me diz respeito").

Em Casamento e divórcio no ensino de Manuel de Andrades, PEREIRA COElHo descreve o processo de legalização da união de facto no Direito português, focado no Direito Civil, sobretudo a partir da Reforma de 1977, e culminando na Lei $n .{ }^{\circ} 135 / 99$, de 28 de agosto, que pela primeira vez institucionalizou a união de facto num diploma legal ${ }^{6}$. Nesse texto, que registou a alocução proferida num ciclo de conferências ocorrido entre Dezembro de 1999 e Abril de 2000, PEREIRA COELHO aludiu à expetativa de vir

3 Cfr. Coelho, Francisco Manuel Pereira (1981) pp. 11 e 12, nota (3), e (1986) pp. 11 a 13, nota (5). Na $4^{a}$ Edição da versão impressa, o elenco dos efeitos da união de facto ocupa já 30 páginas (pp. 63 a 93).

${ }^{4}$ Cfr. Coelho, Francisco Manuel Pereira e Oliveira, Guilherme de, $2^{a}$ edição (2001), p. 83. As ulteriores edições seguem a mesma arrumação ( $3^{a}$ Edição (2003), p. 99; $4^{\mathrm{a}}$ Edição (2008), p. 51.

5 Coelho, Francisco Manuel Pereira (2001).

${ }^{6}$ Cfr. ob. cit., pp. 65-66. PEREIRA COELHO conclui que a lei procedeu apenas, em boa parte, a um sumário de medidas de proteção que já vinham de legislação precedente (ob. cit., p. 66). 
a ser introduzido em Portugal um instituto destinado a legalizar formas de organização da vida em comum entre pessoas do mesmo sexo, mencionando legislação já existente nos direitos francês e belga com essa finalidade ${ }^{7}$. Nas duas últimas edições impressas do Volume I do Curso de Direito da Família, publicadas já na vigência da LUF, PEREIRA COELHO distingue entre a união de facto entre pessoas de sexo diferente e a união de facto entre pessoas do mesmo sexo ${ }^{8}$.

No momento em que escrevo, a Lei . $^{\circ}$ 9/2010, de 31 de maio, veio permitir o casamento civil entre pessoas do mesmo sexo; e o artigo 1. ${ }^{\circ}$,.$^{\circ}$ 2, da LUF, na redação que lhe foi dada pela Lei n. ${ }^{\circ} 23 / 2010$, de 30 de agosto, contém uma noção de união de facto: "A união de facto é a situação jurídica de duas pessoas que, independentemente do sexo, vivam em condições análogas às dos cônjuges”. Este diploma introduziu outras alterações na LUF, aguardando-se ainda o juízo que merecerão a PEREIRA COELHO nas páginas da próxima edição do Curso de Direito da Família.

Os escritos de Pereira COElHo sobre a união de facto deram frutos naqueles que ficaram para sempre seus alunos, GUILHERME DE OlIVEIRA ${ }^{9}$, CAPElO DE SOUSA ${ }^{10}$, FRANÇA PITÃO ${ }^{11}$, eu própria ${ }^{12}$, e noutros autores que investigaram a partir do seu ensino, sobretudo SALTER CID ${ }^{13}$, mas também HEINRICH HÖRSTER ${ }^{14}$ e CRISTINA

7 Ob. cit., p. 68-70.

${ }^{8}$ Cfr. Coelho, Francisco Manuel Pereira, e Oliveira, Guilherme de (2003), pp. 100-101, e 112-114; (2008), pp. 52-53, e 64-66. A vigência da Lei 135/99, de 28 de agosto, foi breve, sendo substituída pela Lei $7 / 2001$, de 11 maio, não tendo por isso sido objeto de tratamento autónomo nas páginas das diferentes edições impressas do Curso de Direito da Família.

9 OliveIRA, Guilherme de (2010).

10 SOUSA, Rabindranath Capelo de (1995).

11 PITÃo, António França (2000), (2011).

12 XAVIER, Rita Lobo (2002), (2004), (2005).

13 CID, Nuno de Salter (2005), (2010).

${ }^{14}$ HÖRSTER, Heinrich (2001). 
DIAS $^{15}$. A eles voltamos sempre, procurando imitar aquelas qualidades que tão bem foram resumidas por TEIXEIRA RIBEIRO e que repito porque não saberia dizê-lo melhor: "o saber de raiz, a clareza e elegância de expressão; a dedicação ao estudo; a seriedade na investigação e no ensino, que nada mais é, aliás, do que um aspecto da exemplar dignidade da sua vida"16.

\section{A união de facto no ensino de Francisco Pereira Coelho}

\subsection{A consagração do termo "união de facto" pela Reforma de 1977}

A expressão" união de facto" foi utilizada pela primeira vez na epígrafe do artigo $20200^{\circ}$ do CC, que concedia àquele que vivesse "em condições análogas às dos cônjuges" com o falecido, o direito a alimentos em relação à herança do falecido. A expressão foi adotada por PEREIRA COELHO para designar a situação das pessoas que, não sendo casadas, vivem como se o fossem ${ }^{17}$. A partir do momento em que a LUF também fixou essa terminologia, PEREIRA COELHO passou a justificar o seu uso na coincidência com a opção legal18. Por terem em Portugal uma "conotação pejorativa”, afastou também o termo "concubinos", que empregou ainda nas últimas versões policopiadas do Curso de Direito da Família, passando a

15 DIAS, Cristina Araújo (2005), (2012). Também será de referir a dissertação de NETO, Renato de Oliveira (2006), integrada na investigação promovida por GUILHERME DE OLIVEIRA.

16 Estas palavras foram escritas por TEIXEIRA RIBEIRO, que tinha assumido a direcão da Revista de Legislação e de Jurisprudência em virtude do falecimento de PIRES DE LIMA, para saudar o início da participação de PEREIRA COELHO no corpo editorial da Revista, em Maio de 1971 (cfr. Revista de Legislação e de Jurisprudência (RLJ), Ano 104..$^{\circ}$ 1971-1972).

17 Cfr. Coelho, Francisco Manuel Pereira (1981) pp. 11 e 12, nota (3)), e (1986) pp. 11 a 13 , nota (5).

18 Coelho, Francisco Manuel Pereira e Oliveira, Guilherme de (2001), p. 85; (2003), p. 101; (2008), p. 53. 
referir-se aos sujeitos da relação preferencialmente como "membros da união de facto"19.

\subsection{A união de facto e a Constituição da República Portuguesa de 1976}

A abordagem da união de facto numa perspetiva constitucional ocorre, em primeira linha, em face do n. 1 do artigo $36 .^{\circ}$ da CRP, nos termos do qual "Todos têm o direito de constituir família e de contrair casamento". Alguns autores sustentaram que esta norma reconhecia implicitamente a união de facto como relação jurídica familiar. PEREIRA COELHO sempre considerou que tal conclusão não poderia ser retirada do texto constitucional, rejeitando a interpretação segundo a qual o legislador ordinário estaria obrigado a reconhecer a união de facto como relação jurídica familiar ${ }^{20}$. A leitura que propõe em face da norma constitucional ficou delineada desde a sua alocução de 1984, publicada em 198621, e foi sendo aprimorada até à mais recente edição do Curso de Direito da Família (2008). É este, em resumo, o seu entendimento:

- Em face do artigo $36 .^{\circ}$, n. $^{\circ} 1$, da CRP não pode tirar-se qualquer argumento no sentido da qualificação da união de facto como relação de família 22 .

- A lei que equiparasse inteiramente a união de facto ao casamento seria inconstitucional, em face do "direito de não contrair casamento", por um lado, e em face do "direito de casar", por outro ${ }^{23}$.

19 Ob. e loc. cits. Sobre a dificuldade na escolha de palavras e expressões para designar a comunhão de vida à margem do casamento, exaustivamente, cfr. CID, Nuno de Salter (2005), pp. 37-53.

20 Cfr. Curso de Direito da Família polic. (1981), pp. 11 e 62-63, (1986), pp. 65 e 67, Curso de Direito da Família (2008), pp. 55 e 117-119.

${ }^{21}$ Cfr. "Casamento e família» (1986), pp. 4 e 5; “Anotação...”, RLJ, Ano 119. ${ }^{\circ}$, p. 375.

22 Curso... (2008) pp. 55 e 118.

23 Curso ... (2008) p. 58. 
- Se os efeitos gerais do casamento fossem extensivos à união de facto, poderia considerar-se violado o princípio da "proteção do casamento" 24 .

PEREIRA COELHO analisou ainda a questão considerando o princípio da proteção da família expresso no artigo $67^{\circ}$ da CRP: este princípio não impõe ao legislador ordinário a atribuição de efeitos favoráveis à união de facto, mas também não proíbe que lhe "conceda os efeitos que tenha por adequados e justificados" 25 .

Depois de ter reconhecido o direito à vida e o direito à integridade física e moral, o artigo $260^{\circ}$ da CRP tipifica "outros direitos pessoais". A quarta revisão constitucional, ocorrida em 1997 , acrescentou no n. $^{\circ} 1$ do artigo $26 .^{\circ}$ a referência ao "direito ao desenvolvimento da personalidade". Na $2^{a}$ edição do Curso de Direito da Família, PEREIRA COElHo completou o enquadramento constitucional da união de facto com a referência ao princípio da proteção da união de facto decorrente do direito ao desenvolvimento da personalidade, reconhecido no artigo $26 .^{\circ}$ da CRP ${ }^{26}$. A "legislação que proibisse a união de facto ou a penalizasse, impondo sanções aos membros da relação e coarctando de modo intolerável o direito de as pessoas viverem em união de facto, seria pois manifestamente inconstitucional" ${ }^{27}$. Na verdade, viver em união de facto "é uma opção de vida, uma manifestação do direito ao livre desenvolvimento da personalidade" 28 .

Finalmente, também é ponderado neste contexto o princípio da igualdade, consagrado no artigo $13 .^{\circ}$ da CRP. Tal princípio apenas proíbe discriminações arbitrárias, pelo que "um tratamento

\footnotetext{
24 "Casamento e divórcio" (2001), pp. 67 e 68; Curso... (2008), pp. 58 e 113 e 114.

25 "Anotação...", RLJ, Ano $120 .^{\circ}$, p. 84.

26 Curso ... (2001), p. 88.

27 Curso... (2008) p. 56.

28 Curso ... (2008) p. 77.
} 
diferente das duas situações, em que as pessoas que vivam em união de facto, não tendo os mesmos deveres, não tenham em contrapartida os mesmos direitos das pessoas casadas, mostra-se assim conforme ao princípio da igualdade, que só quer tratar como igual o que é igual e não o que é diferente, não havendo base legal para estender à união de facto as disposições que ao casamento se referem" 29 .

\subsection{A inventariação dos efeitos reconhecidos pela lei à união de facto e a natureza jurídica desta}

As primeiras referências de PEREIRA COELHO à união de facto consubstanciam uma inventariação dos efeitos que a lei lhe concede $^{30}$. Esse inventário baseia-se numa arrumação segundo os efeitos desfavoráveis aos sujeitos da relação e os efeitos favoráveis aos mesmos $^{31}$, acabando com a conclusão de que, naquela fase do Direito português, a união de facto não devia considerar-se "para a generalidade dos efeitos como relação de família", sobretudo tendo em conta que as normas jurídicas civis que conferiam à união de facto "uma proteção específica eram em pequeno número"32.

No entanto, entendia que a união de facto se deveria qualificar "como relação de família para efeitos de locação, tanto mais que o Código Civil conhecia no quadro das relações locatícias "uma outra noção de "família" mais ampla e menos técnica do que a do artigo 1576." , que abrangia "quaisquer parentes ou afins e, inclusivamente

29 Curso... 2008, p. 57.

30 Cfr. Curso... polic. (1981), p. 11; cfr. "Casamento e família...» 1986; cfr. "Anotação..." RLJ Ano 120. ${ }^{\circ}$. Nestes textos procede ao recenseamento dos dados legais e jurisprudenciais em que se traduzia na altura a proteção da união de facto. Para uma descrição exaustiva das disposições legais dispersas que, no período ulterior à Constituição da República Portuguesa de 1976 e até finais de 2004, vieram atribuir efeitos à união de facto, cfr. CID, Nuno de Salter (2005) pp. 572- 696.

31 "Anotação...", RLJ, Ano $120 .^{\circ}$ pp. 80-81.

32 "Anotação...", cit. p. 82. 
serviçais, que vivam habitualmente em comunhão de mesa e habitação com o locatário"33.

É importante notar que, nos primeiros escritos, PEREIRA COELHO incluía no elenco dos efeitos favoráveis aos sujeitos da união de facto outras situações para além das expressamente referidas em normas legais. Assim, escreveu que, embora não havendo lugar a indemnização pelos danos provocados pela ruptura da relação, "poderá considerar-se como cumprimento de obrigação natural e sujeito ao respetivo regime jurídico tudo o que tenha sido voluntariamente prestado na sequência da rotura"34. No caso de lesão de que proveio a morte, o autor da lesão será igualmente obrigado a reparar ao outro os danos sofridos, sempre que possa entender-se, em face das circustâncias do caso, que o falecido prestava alimentos ao sobrevivo, no cumprimento de uma obrigação natural (art. $495 .^{\circ}$, n. ${ }^{\circ}$ 3 , isto se se entender que se pode falar de uma obrigação natural). Ainda refere o problema da liquidação do património adquirido pelo esforço comum, dando notícia da jurisprudência francesa e brasileira que realizava tal liquidação segundo os princípios das sociedades de facto ${ }^{35}$.

É igualmente de sublinhar que, a partir da edição de 2001 do Curso de Direito da Família, a arrumação dos efeitos da união de facto em efeitos favoráveis e efeitos desfavoráveis foi abandonada.

Importa assinalar a forma como, na ausência de definição legal, procedia à caracterização da união de facto. Na anotação publicada na Revista de Legislação e de Jurisprudência, adota a fórmula do artigo 2020. ("comunhão de vida em condições análogas às dos

33 "Anotação...", cit. p. 83.

${ }^{34}$ No Curso de Direito da Família de 2008, não exclui a possibilidade de a ruptura da união de facto, em determinadas circunstâncias poder originar a obrigação de reparar os prejuízos causados (p. 81).

35 Curso de Direito da Família, polic. (1981) p. 12, em nota; Curso de Direito da Família, polic. (1986), p. 12 em nota; "Casamento e família", p. 17; "Anotação ...», RLJ, Ano $120 .^{\circ}$, p. 81. 
cônjuges") e caracteriza a união de facto como a relação em que "o homem e a mulher vivem como se fossem casados" sem o serem ${ }^{36}$. A vida em comum em união de facto será uma comunhão de vida "materialmente e sociologicamente" igual à comunhão conjugal, pelo que deveria compreender os três aspetos em que se desdobra a comunhão conjugal: comunhão de leito, comunhão de mesa e comunhão de habitação ${ }^{37}$.

Será a partir da apreciação dos efeitos atribuídos pela lei à união de facto que PEREIRA COELHO concluirá que a relação entre os respetivos sujeitos não será uma relação familiar "para a generalidade dos efeitos", muito embora possa haver "domínios em que, excecionalmente, ela merece essa qualificação"38. Assim, em princípio, no ordenamento jurídico português, por opção do legislador ordinário, a união de facto não é uma relação familiar. PEREIRA COELHO integra a união de facto no grupo das relações que designa como "parafamiliares": aquelas relações em cuja regulação legal não se reconhecem as características típicas da disciplina das relações familiares, mas que são conexas com elas ou a que a lei reconhece alguns dos seus efeitos ${ }^{39}$.

\section{3. A "institucionalização" da união de facto}

A Lei n. ${ }^{\circ}$ 135/99, de 28 de agosto, referia-se à "situação jurídica das pessoas de sexo diferente que vivem em união de facto" (art. 1. ${ }^{\circ}$, n. ${ }^{\circ}$ 1), e representou para PEREIRA COELHO a "institucionalização" da união de facto em Portugal ${ }^{40}$. A expressão "institucionalização"

\footnotetext{
36 "Anotação ..." pp. 85-86.

37 "Anotação ..." p. 86.

38 Cfr.; "Anotação ...», RLJ, Ano 120. ${ }^{\circ}$, p. 84; Curso de Direito da Família (2008),

39 Curso de Direito da Família (2008), p. 51.

40 Cfr. Curso... (2001), p. 92. PEREIRA COELHO apontava para algum "voluntarismo" da parte do legislador (cfr. "Casamento e divórcio" (1986), p. 66).
} pp. 59 e 60. 
reporta-se ao facto de ter passado a haver um diploma legal a reunir medidas de proteção das uniões de facto que até então estavam dispersas por regulação avulsa. Esta lei teve um breve período de vigência, sendo substituída pela Lei $n .^{\circ} 7 / 2001$, de 11 de maio, que veio dar relevância jurídica à união de facto entre pessoas do mesmo sexo.

PEREIRA COELHO, para quem a relevância jurídica da união de facto se fundava na analogia com a comunhão de vida conjugal e na aparência externa de casamento em que terceiros podem confiar, procedeu à distinção entre as diferentes uniões de facto. Com efeito, uma vez que a lei ainda não permitia o casamento entre pessoas do mesmo sexo, haveria que distinguir entre as uniões de facto heterossexuais e as uniões de facto entre pessoas do mesmo sexo, diferenciando a disciplina aplicável a umas e outras ${ }^{41}$. Tal distinção era plenamente justificável, uma vez que se podia afirmar que apenas os unidos de facto de sexo diferente viviam "em condições análogas às dos cônjuges", com uma aparência externa de casamento, não existindo tal analogia e aparência relativamente aos unidos de facto do mesmo sexo. A distinção implicava o entendimento segundo o qual só haveria equiparação entre a união de facto entre pessoas de sexo diferente e a união de facto entre pessoas do mesmo sexo para os efeitos previstos nos artigos $3 .^{\circ}$ e $5^{\circ}$ da Lei $7 / 2001^{42}$; "relativamente a todos os efeitos da união de facto não previstos nestes artigos, não existiria base legal para estender à união de facto entre pessoas do mesmo sexo disposições que foram pensadas apenas para a união de facto entre pessoas de sexo diferente" 43 . Nesta ordem de ideias, sustentou igualmente que não teria aplicação à união de

${ }^{41}$ Cfr. Pereira Coelho e GuIlherme De Oliveira, Curso de Direito da Família (2008), pp. 100, e 113 e 114.

42 Curso... (2008), p. 53 e p. 65.

43 Curso... (2008), p. 66. 
facto entre pessoas do mesmo sexo o artigo $2020 .^{\circ}$ do CC, uma vez que o direito a exigir alimentos da herança do falecido não estava compreendido no artigo $3 .^{\circ}$ da Lei n. ${ }^{\circ} 7 / 2001$, de 11 de maio ${ }^{44}$. Por outro lado, a diversidade de sexos não podia deixar de exigir-se relativamente aos efeitos da união de facto que pressupõem essa diversidade, como seria o caso dos efeitos previstos nos artigos 1911. ${ }^{\circ}$, n. $^{\circ} 3$, e $\left.1871 .^{\circ}, \mathrm{n} .{ }^{\circ} 1, c\right)^{45}$.

\section{4. A noção de união de facto}

Penso ser legítimo afirmar que, mesmo após a "institucionalização" da união de facto, PEREIRA COELHO continuou a ter em consideração uma noção geral dessa forma de comunhão de vida, mais abrangente do que a prevista nos dois diplomas legais que sucessivamente estabeleceram medidas de proteção para a mesma.

$\mathrm{Na}$ verdade, o primeiro título da Divisão dedicada à União de Facto no Curso de Direito da Família diz respeito à noção de união de facto, muito embora nem a Lei n. ${ }^{0}$ 135/99, de 28 de agosto, nem a Lei n. ${ }^{\circ} 7 / 2001$, de 11 de maio, na primitiva redação, definissem essa situação ${ }^{46}$. Na ausência de uma definição legal, PEREIRA COELHO caracterizava a união de facto como "uma relação de vida em comum em condições análogas às dos cônjuges", tal como fazia antes do início da vigência dessas leis, na sequência de alguma legislação anterior ${ }^{47}$. No entanto, esta vida em comum de duas pessoas "como se fossem casadas" apenas se podia referir à relação entre duas pessoas de sexo diferente, que vivessem como marido e mulher ${ }^{48}$.

\footnotetext{
44 Ob. cit. p. 91.

45 Ob. cit. p. 65.

46 Cfr. Curso... (2008), p. 52.

47 Cfr. Curso... (2003) p. 100; Curso... (2008), p. 52.

48 Cfr. Curso... (2003), p. 101; Curso... (2008), p. 53.
} 
Esta noção geral está implicitamente presente noutras páginas. Assim acontece quando, ao mencionar a "constituição da relação", escreve que a união de facto se constitui "quando os sujeitos da relação se juntam”9, acrescentando que não é fácil saber quando é que a "união de facto se inicia", embora esse facto seja importante, "pois só a partir dessa data se contam os dois anos que devem decorrer para que a união de facto produza os efeitos previstos na lei" ${ }^{\circ}$. Esta noção geral também está presente quando, refletindo sobre as formas que a união de facto pode revestir e as motivações que a determinam, indicava que, por vezes, existe um impedimento legal temporário à celebração do casamento, por exemplo, o facto de um dos sujeitos estar ligado por um vínculo matrimonial ainda não dissolvido. Com efeito, o casamento impede a relevância jurídica da união de facto, por disposição expressa da lei, pelo que PEREIRA COELHO tem em mente uma noção de união de facto não coincidente com a prevista na lei ${ }^{51}$. Esta questão tem importância sobretudo quando se trata de saber se os pressupostos previstos na LUF para a relevância jurídica da união de facto apenas devem estar presentes quando os seus membros pretendem beneficiar das medidas de proteção conferidas pela mesma lei, ou se também têm de verificar-se sempre que terceiros queiram opor-lhes efeitos desfavoráveis ${ }^{52}$. Para Pereira Coelho parece fundamental neste contexto a distinção entre efeitos favoráveis e efeitos desfavoráveis aos membros da união de facto ${ }^{53}$. Com efeito, apenas beneficiarão dos efeitos favoráveis atribuídos pela LUF as situações de vida em

49 Cfr. Curso...(2001), p. 93; Curso... (2003), p. 110; Curso ... (2008), p. 62.

50 Curso ... (2001), p. 94; Curso ... (2003), p. 110; Curso... (2008), p. 62.

${ }^{51}$ Curso ... (2001), p. 86; Curso ... (2003), p. 102; Curso ... (2008), p. 54; cfr. os artigos $2 .^{\circ}, c$ ), da Lei $n .{ }^{\circ} 135 / 99$, de 28 de agosto, e da Lei $n .{ }^{\circ} 7 / 2001$, de 11 de maio.

52 Sobre este problema, veja-se CID, Nuno de Salter (2005), pp. 570-571, e passim, a propósito de "efeitos desfavoráveis".

53 SALTER CID refere uma terceira categoria de efeitos, os efeitos "neutros", para indicar as "normas que, consoante as circunstâncias dos destinatários, podem ser 
comum em condições análogas às dos cônjuges com duração superior a dois anos, em relação às quais não se verifiquem nenhuma das circunstâncias impeditivas dos efeitos referidas no artigo $2 .^{\circ} \mathrm{da}$ mesma lei. Quando se tratar de terceiros que pretendam invocar a união de facto, para obter a produção de efeitos desfavoráveis aos unidos de facto, já não será necessária a verificação de todos aqueles pressupostos.

\subsection{Destino da casa de morada comum no caso de dissolução da união de facto por ruptura ou por morte}

A semelhança entre a união more uxorio e o casamento residirá sobretudo na coabitação entre o homem e a mulher, que compreende os três aspetos classicamente apontados para a coabitação conjugal: viver como as pessoas casadas envolve a comunhão de habitação, de mesa e de leito ${ }^{54}$. Por comunhão de habitação entende-se a adoção de uma residência comum, sendo o imóvel propriedade de um ou de ambos, ou sendo arrendado, por um ou por ambos. Comunhão de mesa significa que será possível "afirmar a existência de qualquer espécie de economia doméstica do "casal", isto é, o recurso à figura da sinédoque exprime a existência de uma economia comum, de um orçamento comum e de partilha de despesas. A comunhão de leito refere-se ao relacionamento íntimo entre ambos, designadamente às relações sexuais.

A questão do destino da casa de morada comum no caso de dissolução da união de facto apresenta assim um grande interesse prático. Os membros da união de facto adotam a mesma residência mas, ocorrendo a ruptura da relação, apenas um deles poderá permanecer na casa onde viviam, o que conduz a um conflito semelhante

apontadas como portadoras de vantagens ou de inconvenientes para pessoas unidas de facto" (2005), p. 624 e 687.

54 Cfr. COELho, Francisco Manuel Pereira, «Anotação...» cit., p. 85. 
ao que surge em caso de separação conjugal ou de divórcio. Sendo a união de facto dissolvida por morte do membro que era titular exclusivo do direito de propriedade sobre o imóvel onde tinham fixado a residência comum, ou do direito de arrendamento sobre o mesmo, surge igualmente a questão de saber como tutelar o interesse que o membro sobrevivo terá em continuar a residir no local.

Todos os aspetos compreendidos na comunhão de vida dos unidos de facto apontam para a importância da residência comum. O que distingue a relação de união de facto de um relacionamento pontual ou de uma relação de namoro íntimo, será precisamente o facto de os sujeitos da relação viverem na mesma casa. Na verdade, para que se possa dizer que duas pessoas vivem em união de facto, não basta passarem férias ou fins de semana juntas, ou pernoitarem por vezes em casa uma da outra, mesmo que se trate de uma relação que dure muitos anos. "Relações sexuais fortuitas, passageiras, acidentais não configuram pois uma união de facto" 55 .

Sendo a casa de morada o centro da vida em comum dos unidos de facto, PEREIRA COELHO foi sensível à necessidade de resolver o conflito sobre qual dos dois ficaria aí a viver após a ruptura, sustentando inclusivamente, em dado momento, a aplicação analógica de normas cujo teor literal se referia a pessoas ligadas pelo vínculo do casamento. Com efeito, no que dizia respeito ao direito ao arrendamento para habitação, além de sublinhar que a sucessão em tal direito constituía a proteção mais forte da união de facto ${ }^{56}$, entendeu que se poderia transmitir eventualmente ao outro membro da relação, em caso de ruptura. Fundamentava esta solução na igualdade entre os filhos nascidos do casamento e fora do casamento, quando houvesse filhos da relação que tivessem sido

\footnotetext{
55 Curso de Direito da Família, cit. (2008), p. 84.

56 Esta verificação levava PEREIRA COELHO à conclusão de que a união de facto constituia uma relação familiar para efeitos de locação (cfr. "Anotação ...", cit., RLJ, Ano $120 .^{\circ}$, p. 83).
} 
confiados ao progenitor não arrendatário ${ }^{57}$. Assim, defendeu a aplicação analógica da antiga norma do artigo $1110 .^{\circ}$, n. ${ }^{\circ}$ s 2 a 4 do CC, e discordou do Assento do STJ de 23 de abril de 1987, ainda antes de o Tribunal Constitucional o declarar inconstitucional ${ }^{58}$. Nessa medida, também acolheu com naturalidade o artigo $4 .^{\circ}$ da LUF que mandou aplicar à ruptura da união de facto as soluções normativas preconizadas para o destino da casa de morada comum em caso de divórcio, com as devidas adaptações ${ }^{59}$. A aplicação das referidas normas à união de facto envolve uma delicada atividade de adequação a esta realidade, uma vez que tais normas pressupõem um processo de divórcio a decorrer em Tribunal ou na Conservatória do Registo Civil, processo que não existe no caso da ruptura da união de facto. Assim, Pereira Coelho considerou que o pedido de constituição de um direito ao arrendamento, nos termos do artigo $1793 .^{\circ}$ do CC, ou de transmissão do direito ao arrendamento para o não arrendatário, de acordo com o artigo $1105 .{ }^{\circ}$ do $\mathrm{CC}^{60}$, devia cumular-se com o de declaração judicial de dissolução da união de facto, tendo em conta o disposto no artigo $8 .^{\circ}, \mathrm{n} .^{\circ} 2$ da LUF ${ }^{61}$. Já quanto à hipótese de transmissão do direito ao arrendamento por acordo (artigo $1105 .^{\circ}$, n. $^{\circ} 1$, do CC), embora PEREIRA COELHO não o diga expressamente, não pode deixar de entender-se que tal acordo terá sempre de ser homologado por sentença para poder ser oposto ao senhorio. A LUF manteve a transmissão do direito ao arrendamento para habitação, por morte do arrendatário, à

57 Cfr. ob. cit., p. 81.

58 Cfr. ob. cit. p. 81, nota 6. Quanto à jurisprudência do Tribunal Constitucional, cfr. Curso de Direito da Família (2008), p. 82.

59 Cfr. Curso..., (2001), p. 110, e (2003), p. 129, com referência à remissão para o artigo $84 .^{\circ}$, n. ${ }^{\circ} 1$, do RAU no que respeita ao direito ao arrendamento; (2008), p. 81 , reportando à remissão para o artigo $1105 .^{\circ}$ do CC.

${ }^{60} \mathrm{Na}$ edição do Curso de Direito da Família mais recente a remissão considerava-se feita para o artigo $1105 .^{\circ}$ do CC.

61 Cfr. Curso ... (2008), p. 83. 
pessoa que com ele vivia em união de facto há mais de dois anos, colocando-a, na opinião de PEREIRA COELho, em posição mais favorável, logo a seguir ao cônjuge e aos descendentes, desde que à data da morte o arrendatário não fosse casado ou, sendo casado, estivesse separado de pessoas e bens ${ }^{62}$. A questão passou a estar regulada no n. ${ }^{\circ} 1$ do artigo $1106 .^{\circ}$ do CC, na redação dada pela Lei n. ${ }^{\circ}$ 6/2006, de 27 de fevereiro (Novo Regime do Arrendamento Urbano), segundo o qual o arrendamento para habitação não caducava por morte do arrendatário quando lhe sobrevivesse "cônjuge com residência no locado ou pessoa que com o arrendatário vivesse no locado em união de facto e há mais de um ano" (alínea a)); ou "pessoa que com ele residisse em economia comum e há mais de um ano" (alinea b)). Esta norma suscitou a PEREIRA COELHO muitas dúvidas de interpretação relativamente à sua aplicação no contexto da união de facto, acabando por concluir que a transmissão do direito ao arrendamento para o membro sobrevivo dependeria não apenas da alegação e prova dos pressupostos exigidos para a relevância jurídica da união de facto na LUF - isto é, a vida em comum há mais de dois anos, nos termos do artigo $1 .^{\circ}, \mathrm{n} .^{\circ} 2$, e a não ocorrência de nenhuma das circunstâncias previstas no artigo $2 .^{\circ}$-, mas também seria necessário que pelo menos um ano tivesse sido vivido no local arrendado ${ }^{63}$. Sendo o falecido titular do direito

62 Curso..., (2008), p. 113.

63 Cfr. Curso ... (2008), pp. 85 e 86. A minha interpretação também tinha sido no sentido de que a referência à união de facto supunha a sua relevância jurídica nos termos da LUF (XAVIER, Rita Lobo (2008), p. 1040. Aliás, já tinha feito idêntica observação relativamente à proposta do Governo anterior ao que apresentou a proposta do NRAU (o chamado RNAU) (cfr. XAVIER, Rita Lobo (2004), pp. 332 e 333. No meu entendimento, contudo, deveria bastar a demonstração da comunhão de vida durante pelo menos um ano no locado, ou, que a união de facto durou mais de dois anos, mesmo que fora do locado. Na verdade, não se compreenderia que o membro sobrevivo de uma união que exista há dez anos, por exemplo, não beneficie da transmissão da posição de arrendatário pelo simples facto de ter mudado de casa há menos de um ano; além disso, o requisito da duração temporal previsto na lei em termos gerais existe como indício de alguma estabilidade da vida em co- 
de propriedade sobre a casa de morada comum, a LUF concedeu ao sobrevivo o direito real de habitação pelo prazo de cinco anos, entendendo PEREIRA COELHo que o direito tinha "fraca proteção, pois as disposições que o reconheciam não se aplicariam se ao falecido sobrevivessem descendentes com menos de um ano ou que com ele vivessem há mais de um ano e pretendessem continuar a viver na casa, ou ainda se houvesse disposição testamentária em contrário ${ }^{64}$. PEREIRA COELHO qualificava este direito atribuído pela lei como um "legado legítimo", fazendo notar que a lei apenas concedia ao sobrevivo o direito real de habitação na casa e não o direito de uso do recheio, como acontecia em relação ao cônjuge sobrevivo, no caso previsto no artigo $2103 .^{\circ}$ - A 65 . A LUF conferiu ainda ao membro sobrevivo da união de facto o direito de preferência na venda da casa pelo prazo de cinco anos, o qual também não se aplicava quando ao falecido sobrevivessem descendentes com menos de um ano de idade ou que com ele vivessem há mais de um ano e pretendam continuar a viver na casa ou quando houvesse disposição testamentária em contrário ${ }^{66}$.

\section{6. Os efeitos patrimoniais entre os membros da união de facto}

Os membros da união de facto não estão vinculados por deveres recíprocos, nem as relações patrimoniais, entre ambos e em relação a terceiros, estão reguladas pela lei de forma especial, como acontece com os cônjuges. A legalização da união de facto em Portugal nunca envolveu normas sobre estas questões. No entanto, um dos aspetos

mum. Assim, o objetivo de dar continuidade ao gozo do local eleito como morada comum atinge-se relativamente a uma união que foi dissolvida por morte, mesmo que ainda não tenham decorrido dois anos, desde que tenha decorrido um ano no locado; pois, nesse caso, o projeto de vida em comum terá sido interrompido pela morte, não havendo indício de instabilidade (XAVIER, Rita Lobo, (2008), p. 1041).

${ }^{64}$ Curso de Direito da Família, (2001), p. 113

65 Ob. cit., (2001), p. 113.

66 Ob. cit. (2001), p. 113. 
mais relevantes da vida "em condições análogas às dos cônjuges" é a existência de uma forma de "economia doméstica" comum ${ }^{67}$. Com efeito, entre as pessoas que vivem em união de facto estabelece-se uma comunhão de interesses patrimoniais, apesar da inexistência de um vínculo matrimonial, o que muitas vezes explica soluções da doutrina e da jurisprudência estrangeiras encontradas para resolver problemas relativos à divisão dos bens adquiridos durante a vida em comum, ou a pedidos de compensação pela colaboração prestada no contexto da relação, ou à responsabilidade de ambos por dívidas decorrentes de despesas com a vida do lar ${ }^{68}$. Muitas dessas soluções resultam da aplicação por via da analogia de normas previstas para a relação conjugal.

PEREIRA COElHO foi sensível ao facto de a coabitação em "condições análogas às dos cônjuges" compreender esta "espécie de economia doméstica”. Assim, embora não chegue ao ponto de afirmar que existe entre os membros da união de facto um dever de assistência, admite que possam regular a contribuição de cada um para as despesas da casa, o que influirá no montante das suas despesas individuais ${ }^{69}$. Também conclui que os membros da união de facto são estranhos um ao outro, ficando as suas relações patrimoniais sujeitas ao regime geral das relações obrigacionais e reais ${ }^{70}$. No entanto, aceita que os companheiros possam regular os efeitos patrimoniais da sua relação através dos chamados "contratos de coabitação", incluindo, por exemplo, cláusulas a inventariar os bens levados para a união, a estabelecer regras de divisão dos bens adquiridos na vigência da união, a fixar presunções relativas à titularidade dos bens adquiridos ou às quantias depositadas em contas bancárias, a

\footnotetext{
67 Ob.cit. (2008), p. 72.

68 Cfr. XAVIER, Rita Lobo (2000), p. 475-478.

69 Curso de Direito da Família, cit. (2008), p. 69.

70 Ob. cit., pp. 72 e 80.
} 
regular a contribuição de cada um dos conviventes para as despesas do $\operatorname{lar}^{71}$. Não encontrando razões para considerar inválidos tais contratos, PEREIRA COELHO sustentou que cada cláusula deveria ser apreciada segundo as regras do Direito comum ${ }^{72}$. Entendeu ainda ser razoável estender à união de facto o artigo 1691. ${ }^{\circ}$, al. b) do CC, em consideração da aparência de vida matrimonial criada pelos membros da união de facto, suscetível de suscitar a confiança de terceiros. Concluía assim que os sujeitos da relação poderiam ser considerados solidariamente responsáveis pelas dívidas contraídas por qualquer um deles para acorrer aos encargos da vida em comum 73 . No que diz respeito à divisão do património adquirido durante a vida em comum, PEREIRA COELHO refletia já em 1981 sobre este assunto, referindo a solução seguida pelas jurisprudência francesa e brasileira no sentido de proceder a uma liquidação segundo os princípios das sociedades de facto quando os respetivos pressupostos se verificassem ${ }^{74}$. Mencionava ainda a corrente jurisprudencial a invocar os princípios do enriquecimento sem causa para fundar a obrigação de restituição de um dos membros da união de facto, logrando desse modo a liquidação e divisão do património adquirido pelo esforço de ambos 75 .

\section{7. A prova da união de facto}

O casamento é um dos factos sujeitos a registo civil obrigatório (artigo 1. ${ }^{\circ},{ }^{\circ}{ }^{\circ} 1, c$ ), do Código de Registo Civil (CRC), sendo o registo

71 Ob. cit., pp. 72 e 80. Sobre estes contratos, cfr. NETO, Renato de Oliveira (2006).

72 Ob. cit., p. 73.

73 Ob. cit., pp. 75 e 76. Esta posição é sustentada já no Curso de Direito da Família, polic. (1981), p. 11, nota (3). Cfr. Curso de Direito da Família (2008), onde na página 409 se equaciona inclusivamente a hipótese de aplicação por analogia da alínea $c$ ) do artigo $1691 .^{\circ}$ do CC.

${ }^{74}$ Ob. cit. (1981), p. 12, em nota; Curso de Direito da Família, polic. (1986), p. 13, em nota; Curso ...(2008), p. 80.

75 Curso ...(2008), p. 80. 
o único meio de prova legalmente admitido para quem pretenda invocar os seus efeitos, tendo força probatória plena (artigos $2 .^{\circ} \mathrm{e}$ $3 .^{\circ}$ do CRC, e artigo $371 .^{\circ}$ do CC). A celebração do casamento gera um estado pessoal, o que justifica a sua sujeição a registo civil obrigatório, determinando o estado civil de "casado". No ordenamento jurídico português, a opção do legislador ordinário tem sido sempre contrária à formalização da relação da união de facto, o que torna difícil a demonstração dos factos exigidos pela lei para a sua relevância jurídica, diversamente do que ocorre em outros ordenamentos jurídicos. A relevância jurídica da união de facto depende da sua invocação, em cada caso, pelos interessados. Os membros da união de facto não assumem qualquer compromisso jurídico duradouro, cada um deles podendo romper a relação quando quiser, unilateralmente e sem formalidades. Por isso, o regime legal da união de facto não importa um estado civil diferente e não integra cada um dos membros na família do outro, uma vez que não gera relações de afinidade.

PEREIRA COELHO refere-se à questão da prova da união de facto muito sumariamente, afirmando que, em princípio, se tratará de prova testemunhal, não havendo em regra uma prova preconstituída. Não exclui, no entanto, a prova documental, nomeadamente por meio de "atestados passados pela junta de freguesia da residência dos interessados". Afirma ainda que semelhante documento apenas provará o facto de que os interessados fizeram tal declaração, não provando que a afirmação corresponda à verdade ${ }^{76}$.

76 Cfr. Curso ... (2001), pp. 94-95; Curso ... (2003), pp. 110-111; Curso ... (2008), pp. 62-63. PEREIRA COElHo acrescenta a ressalva de que possa tratar-se de facto "atestado com base nas perceções da entidade documentadora", nos termos do artigo $371 .^{\circ}, \mathrm{n} .{ }^{\circ} 1$ do $\mathrm{CC}$, o que pode acontecer e realmente tem acontecido (cfr. CID, Nuno de Salter (2005), pp. 588, nota 153, 597, notas 174 a 176, onde se descrevem as competências legais atribuídas às juntas de freguesia para "atestar a residência, vida e situação económica dos cidadãos da freguesia”). Os artigos $34 .^{\circ}, 35 .^{\circ}$ e $38 .^{\circ}$ da Lei $n .^{\circ} 169 / 99$, de 18 de setembro, foram, entretanto, revogadas pela Lei $n .^{\circ}$ 


\section{8. A cessação da pensão de alimentos devida por ex-cônjuge}

Uma questão importante, na altura não inteiramente resolvida pelos textos legais, suscitou o interesse de PEREIRA COELHO: saber se a união de facto impede a constituição de um direito a alimentos ou extingue a pensão ou o direito existentes. Por exemplo, poderá a pessoa que vive em união de facto com outra continuar a exigir alimentos ao ex-cônjuge de quem se divorciou, verificadas a necessidade daquele e a possibilidade deste ${ }^{77}$ ? A lei previa a extinção da obrigação alimentar a favor do ex-cônjuge no caso de este contrair novo casamento, mas não no caso de passar a viver em união de facto, e PEREIRA COELHO pronunciou-se no sentido de considerar justificada uma solução que equiparasse neste ponto a união de facto ao casamento ${ }^{78}$.

\section{9. Direito a indemnização no caso de lesão de que proveio a morte de um dos membros da união de facto}

PEREIRA COELHO admitia que, no caso de lesão de que proveio a morte de um dos membros da união de facto, pudesse proceder uma ação proposta pelo sobrevivo com vista a obter uma indemnização pelos danos patrimoniais sofridos, fundada na norma do artigo $495 .^{\circ}$, n. ${ }^{\circ}$ 3, do CC. Na verdade, poder-se-ia considerar que, no caso de o falecido prestar alimentos ao sobrevivo, a prestação, embora não judicialmente exigível, corresponderia ao cumprimento de uma obrigação natural79. No entanto, já não seria assim se estivesse em causa um pedido de indemnização pelos danos não patrimoniais sofridos,

$75 / 2013$, de 12 de setembro. Nesta, cfr. artigos $16 .^{\circ}$, n. ${ }^{\circ} 1$, rr) $17 .^{\circ}$ e $18 .^{\circ}$, n. $\left.{ }^{\circ} 1,1\right)$, n. ${ }^{\circ} 2$, b) e n. ${ }^{\circ} 3$, c).

77 Questão idêntica se pode pôr relativamente à pensão de alimentos fixada sobre a herança do unido de facto falecido, nos termos do artigo $2020 .^{\circ}$ do CC. Cfr. Curso (2001), pp. 106-107; Curso ... (2003), pp. 124-126; (2008), pp. 76-78.

78 Cfr. Curso de Direito da Família (2008), p. 78.

79 Curso ... (2008), p. 87. 
uma vez que o artigo $496 .^{\circ}$, n. ${ }^{\circ}$, indicava, de forma taxativa, as pessoas que teriam direito a ser indemnizadas no caso de morte do lesado, não estando incluído o membro sobrevivo da união de facto ${ }^{80}$. PeReira COELHO, em coerência com o seu entendimento sobre as implicações do princípio da igualdade nestas matérias, sustentou que também não seria legítima, neste caso, a equiparação do unido de facto sobrevivo ao cônjuge sobrevivo. Nesta ordem de ideias, também discordou de um acórdão do Tribunal Constitucional que "julgou inconstitucional por violação do artigo $36 .^{\circ}$, n. $^{\circ} 1$, conjugado com o princípio da proporcionalidade, a norma do $\mathrm{n} .{ }^{\circ} 2$ do artigo 496. do CC, na parte em que, em caso de morte da vítima de um crime doloso, exclui a atribuição de um direito de 'indemnização por danos não patrimoniais', pessoalmente sofridos pela pessoa que convivia com a vítima em situação de união de facto estável e duradoura, em condições análogas às dos cônjuges"\$1.

\subsection{Reparação dos prejuízos causados em caso de injusta ruptura da união de facto}

Nos seus primeiros escritos sobre a união de facto, PEREIRA COELHO afirmou não haver lugar a indemnização pela ruptura da união de facto, mas que poderia, todavia, considerar-se cumprimento de obrigação natural, e sujeito como tal ao respetivo regime, o que tenha sido prestado voluntariamente na sequência da ruptura ${ }^{82}$.

Nas edições impressas do Curso de Direito da Família não exclui contudo "a possibilidade de a ruptura da união de facto, em determinadas circunstâncias, se mostrar clamorosamente injusta,

80 Curso ... (2008), p. 87.

${ }^{81}$ Acórdão n. ${ }^{\circ}$ 275/2002 da $2^{\text {a }}$ Secção do Tribunal Constitucional de 19.06.2002 (Diário da República, II Série, de 24.07.2002, p. 12896-12902, com declaração de voto de vencido do Conselheiro Bravo Serra, acompanhado pelo Conselheiro Cardoso da Costa). Cfr. Curso... (2008), pp. 87-88.

82 Cfr. "Anotação...», RLJ, Ano $120 .^{\circ}$, p. 80. Curso de Direito da Família, polic. (1981), p. 11, em nota; (1986), p. 12, em nota. 
com manifesto excesso dos limites impostos pela boa fé ou pelos bons costumes ao exercício do direito", admitindo que a proibição do abuso do direito possa obrigar aquele que rompe a relação a reparar os prejuízos causados ao outro ${ }^{83}$.

\subsection{Conclusões}

Atrevo-me agora a resumir as posições assumidas por PEREIRA COELHO relativamente à união de facto:

1) "Casamento e união de facto são situações materialmente diferentes" 84 . "No casamento, as pessoas pretendem constituir família 'nos termos das disposições do Código Civil'; é isso que não acontece na união de facto em que, pelo contrário, querem manter-se à margem dessas disposições" ${ }^{55}$. Na verdade, "os casados assumem o compromisso de vida em comum; os membros da união de facto não assumem, não querem ou não podem assumir esse compromisso"

Para PEREIRA COELho, os membros da união de facto não estão vinculados pelos deveres assumidos pelos cônjuges ${ }^{87}$. O "tratamento diferente das duas situações, em que as pessoas que vivam em união de facto, não tendo os mesmos deveres, não tenham em contrapartida os mesmos direitos das pessoas casadas, mostra-se assim conforme ao princípio da igualdade, que só quer tratar como igual o que é igual e não o que é diferente, não havendo base legal para estender à união de facto as disposições que ao casamento se referem" 8 .

83 Cfr. Curso de Direito da Família, cit. (2001), p. 109; (2003), p. 129; (2008), p. 81. 84 Ob. cit. (2008), p. 57.

85 Ob. cit. (2003), pp. 213, nota 10, e 105.

86 Ob. cit. (2008), p. 57.

87 Ob. cit. (2008), p. 69.

88 Ob. cit. (2008), p. 57. 
2) "A união de facto só tem os efeitos que a lei lhe atribuir"89. PEREIRA COELHO é favorável ao reconhecimento de efeitos jurídicos à união de facto, entendendo, no entanto, que tais efeitos devem ser contados, não sendo "legítimo estender à união de facto as disposições referentes ao casamento", devendo evitar-se a equiparação dos efeitos do casamento e da união de facto. Assim, o estatuto da união de facto deve situar-se entre duas balizas, não permitindo a CRP nem a penalização da união de facto, nem a sua equiparação ao casamento 90 .

3) A razão da atribuição de efeitos legais à união de facto reside no facto de um homem e uma mulher viverem em comum com aparência de casamento, isto é, em situação análoga à dos cônjuges. Assim, muito embora, em princípio sustentasse que a união de facto apenas teria os efeitos previstos na lei, aceitava a aplicação analógica de determinadas normas reguladoras de alguns aspetos da comunhão de vida conjugal, parecendo-lhe, por exemplo, "razoável estender à união de facto o artigo $1691 .^{\circ}$, al. b), Cciv", para considerar os sujeitos da relação "solidariamente responsáveis (artigo 1695. ${ }^{\circ}$, n. ${ }^{\circ} 1$ ) pelas dívidas contraídas por qualquer um deles para acorrer aos encargos normais da vida em comum"91.

4) "A união de facto não é relação de família para a generalidade dos efeitos", em face das disposições legais aplicáveis; PEREIRA COELHO reconhece, contudo, que poderá haver domínios em que, excecionalmente, merecerá tal qualificação ${ }^{92}$.

5) Os factos enunciados nas várias alíneas do $n .{ }^{\circ} 1$ do artigo $2 .^{\circ}$ da LUF apenas impedem a produção dos efeitos favoráveis

\footnotetext{
89 Ob. cit. (2008) p. 64.

90 Ob. cit., p. 58

91 Ob. cit., p. 76 .

92 Ob. cit., p. 60.
} 
da união de facto, pelo que a união de facto não deverá ser juridicamente irrelevante quando se tratar de salvaguardar interesses legítimos de terceiros ou quando se tirarem consequências desfavoráveis ${ }^{93}$. PEREIRA COELHO faz assim referência a uma noção de união de facto diferente da consagrada na LUF.

6) As disposições legais que protegem a união de facto são imperativas, embora os membros da união de facto possam exercer ou não os direitos que a lei lhes concede, não sendo permitida a renúncia antecipada a esses direitos ${ }^{94}$.

7) Deve fazer-se uma distinção entre uniões de facto entre pessoas de sexo diferente e uniões de facto entre pessoas do mesmo sexo relativamente aos efeitos da união de facto que pressupõem essa diversidade 95 .

8) As relações patrimoniais entre os membros da união de facto ficam sujeitas ao regime geral das relações obrigacionais ou reais, na falta de previsão legal sobre a matéria, não sendo de excluir que a divisão dos bens adquiridos durante a vida em comum se faça segundo os princípios das sociedades de facto, ou os princípios do enriquecimento sem causa ${ }^{96}$.

9) Deve admitir-se o uso da liberdade contratual, nomeadamente para regular os aspetos patrimoniais da relação designadamente através da celebração de um "contrato de coabitação"97.

10) A lei deve prever que a união de facto impede a constituição de um direito a alimentos ou extingue a pensão ou o direito existente, neste ponto equiparando neste ponto a união de facto e o casamento 98 .

\footnotetext{
93 Ob. cit., p. 68-69.

94 Ob. cit. p. 58 , nota 25.

95 Ob. cit. p. 65

96 Ob. cit. pp. 72 e 80.

97 Ob. cit. p. 72

98 Ob. cit. p. 78.
} 
11) No caso de lesão de que proveio a morte, o membro sobrevivo terá direito a ser indemnizado pelos danos que sofreu na medida em que demonstre que recebia alimentos do falecido a título de obrigação natural99.

\section{A união de facto na legislação atual}

\subsection{A noção de união de facto}

A Lei n. ${ }^{\circ}$ 23/2010, de 30 de agosto (Alteração à Lei das Uniões de Facto) introduziu mudanças relevantes na versão originária da Lei n. ${ }^{\circ} 7 / 2001$, de 11 de maio ${ }^{100}$, muitas das quais vieram responder a dúvidas levantadas por PEREIRA COELHO, embora nem sempre no sentido que propugnava. Não sendo possível, neste momento, proceder à apreciação de todas as alterações verificadas, vou restringir-me às mais importantes.

De acordo com o atual n. ${ }^{\circ} 2$ do artigo $1 .^{\circ}$ da LUF, "A união de facto é a situação jurídica de duas pessoas que, independentemente do sexo, vivam em condições análogas às dos cônjuges há mais de dois anos". Existe agora uma definição legal de união de facto, que equipara as uniões de facto entre pessoas de sexo diferente e entre pessoas do mesmo sexo, salvo para efeitos de adoção conjunta (cfr. o artigo $7 .^{\circ}$ da mesma lei). Como vimos atrás, PEREIRA COELho distinguia entre estas duas situações, considerando como análoga à dos cônjuges apenas a vida em comum entre um homem e uma mulher. Os seus escritos, porém, ainda não tiveram em consideração a Lei n. ${ }^{\circ}$ 9/2010, de 31 de maio, que veio permitir o casamento civil entre pessoas do mesmo sexo. Neste momento, o Código Civil designa pelo termo "cônjuges" quer o homem e a mulher casados, quer as

99 Ob cit. p. 88.

100 Cfr. OlIVEIRA, Guilherme de, (2010). 
pessoas do mesmo sexo que contraíram "casamento" civil, muito embora esta opção do legislador ordinário não se compreenda no caso das normas que supõem a diferenciação sexual (como acontece nas que respeitam ao estabelecimento da filiação ou à regulação das responsabilidades parentais relativas a descendência comum). Caberá perguntar se, apesar de tecnicamente correta, a definição legal de união de facto não será excessiva, sobretudo para aqueles que entendem que o vínculo formal entre duas pessoas do mesmo sexo é apenas uma ficção de casamento, legislativamente imposta, mas não correspondente à realidade antropológica subjacente à instituição matrimonial. GUILHERME DE OLIVEIRA informa que se pretendeu tornar claro que todos os efeitos de proteção das uniões de facto devem ser aplicados independentemente de se tratar de uniões do mesmo sexo ou de sexo diferente, com a exceção da possibilidade da adoção conjunta e de serem beneficiários das técnicas de Procriação Medicamente Assistida ${ }^{101}$. A nova redação do artigo $2020 .^{\circ}$ do CC, adotando a expressão "membro sobrevivo da união de facto", confirma a opção legislativa no sentido de equiparar as uniões de facto do mesmo sexo ou de sexo diferente ${ }^{102}$.

Por outro lado, tratando-se de uma definição que se restringe à "situação jurídica", continuará a ser importante distinguir entre as uniões de facto juridicamente relevantes para efeitos da aplicação da LUF e as uniões de facto em que não se verifiquem todos os pressupostos exigidos para a sua aplicação, tal como era preconizado por Pereira COelho. A modificação operada no corpo do artigo $2 .^{\circ}$ aponta igualmente nesse sentido: "Impedem a atribuição de direitos ou benefícios, em vida ou por morte, fundados na união de facto...". Ficou agora claro que o elenco dos impedimentos previstos no artigo $2 .^{\circ}$ diz respeito apenas à produção dos efeitos favoráveis

101 OlIVEIRA, Guilherme de (2010), p. 141.

102 OLIVEIRA, Guilherme de (2010), p. 149. 
à união de facto. Quando se tratar de retirar consequências desfavoráveis da união de facto, ou de salvaguardar interesses legítimos de terceiros, poderá ser invocada a união de facto, mesmo que se verifique algum desses impedimentos ${ }^{103}$.

\subsection{A prova da união de facto}

Foi aditada à LUF uma nova disposição, o artigo $2 .^{\circ}$ - A, cuja epígrafe é "Prova da união de facto". Depois de o n. ${ }^{\circ} 1$ afirmar a possibilidade de ser demonstrada por qualquer meio a realidade dos factos que são pressupostos da relevância jurídica da união de facto, os números seguintes referem-se à prova documental preconstituída. Este artigo destina-se a facilitar a demonstração da realidade desses factos, uma vez que a lei continua sem prever "um registo oficial para as uniões de facto"104. Por outro lado, pretende-se libertar os membros da união de facto de terem de obter uma declaração judicial para certificar a sua relação. Repare-se contudo que a lei continua a fixar o princípio de que a dissolução da união de facto terá de ser judicialmente declarada quando se pretendam fazer valer direitos que dependam dela (artigo $8 .^{\circ}$, n. ${ }^{\circ}$ 2) ${ }^{105}$.

A LUF refere agora expressamente a possibilidade de o resultado probatório poder ser obtido através da apresentação de um atestado da junta de freguesia competente, acompanhado de outros documentos, como a certidão de cópia integral do registo de nascimento e de declaração, sob compromisso de honra, de um ou de ambos, de que vivem em união de facto há mais de dois anos (artigo $2 .^{\circ}-\mathrm{A}$, n. ${ }^{\circ}$ s 2,3 e 4$)$.

103 OLIVEIRA, Guilherme de (2010), p. 141.

104 Ob. cit. p. 143.

105 Quanto a este aspeto resulta agora do texto legal uma exceção relativa às prestações sociais por morte (artigo $6 .^{\circ}, n .^{\circ} 2$ ), de que falarei a seguir no texto. 
Importa sublinhar que a previsão da lei traduz-se apenas na menção da possibilidade de apresentação de documentos para demonstração dos pressupostos da relevância jurídica da união de facto, não conferindo qualquer valor probatório acrescido aos documentos referidos. Continua a ser válida, portanto, a acima referida argumentação de PEREIRA COELHO respeitante aos factos abrangidos pela prova documental e ao seu valor probatório. Assim, a certidão de cópia integral do registo de nascimento de cada um dos interessados destina-se a demonstrar a realidade dos factos referidos no artigo 2. alíneas $a$ ), b) (exceto relativamente à "demência notória"), c) e $d$ ); a certidão do óbito do falecido demonstra a realidade do falecimento de um dos interessados; a declaração emitida pela junta de freguesia comprovará, em regra, apenas o facto de que os interessados fizeram tais afirmações, embora se possa admitir, como se viu atrás, que ateste igualmente, com base na perceção da entidade documentadora, a realidade dos factos por ela abrangidos. Note-se ainda que a declaração da junta de freguesia, em princípio, se referirá apenas ao facto de os interessados terem uma residência comum há mais de dois anos, não abrangendo a natureza do seu relacionamento (muito embora, repita-se, não seja de excluir a hipótese de serem atestados esses factos com base nas perceções da entidade documentadora). Nesta medida, o documento emitido pela junta de freguesia não seria suficiente para demonstrar a união de facto. Na verdade, a LUF não exige apenas a alegação e prova de que duas pessoas residem juntas há mais de dois anos e a falta de impedimentos à sua relevância jurídica; é necessário que se demonstre que vivem em "união de facto". Assim, aquele documento poderá ser proposto para demonstração de que duas pessoas vivem juntas e a duração da sua vida em comum, devendo ainda ser alegados e provados os factos relativos à natureza da sua relação (vida "em condições análogas às dos cônjuges"), factos que, na ausência de atestado respeitante a esses factos com base nas perceções da entidade documentadora, 
pareceria apenas poderem ser demonstrados por via de prova testemunhal. A LUF prevê agora que os próprios interessados apresentem, para demonstração da natureza da sua relação, uma declaração de ambos (ou apenas uma declaração singular, se não for possível obter a de ambos), sob compromisso de honra, "de que vivem em união de facto há mais de dois anos" (art. 2. ${ }^{\circ}-\mathrm{A}$, n. $^{\circ}$ s 2, 3 e 4). O n. ${ }^{\circ} 5$ contém uma advertência sobre a sanção penal das falsas declarações. A referência às consequências penais da prestação de falsas declarações visa promover a correspondência entre as declarações e a realidade, através da ameaça da aplicação da sanção, na expectativa de que as declarações correspondam à verdade.

A previsão da LUF quanto às declarações dos interessados causa-me alguma estranheza. Como é sabido, reconhecida a veracidade deste documento, ele apenas provará que os seus autores fizeram as declarações que lhes são atribuídas, mas os factos que dele constam apenas se consideram exactos na medida em que forem contrárias aos interesses dos seus autores ${ }^{106}$. Tratando-se de declarações sobre factos favoráveis, na medida em que são em concreto idóneos a produzir consequências vantajosas para os declarantes, está sempre presente o risco da credibilidade que decorre do seu interesse em que tais consequências se produzam. O que torna premente a dúvida sobre a sua isenção, uma vez que a declaração é necessária para obter a sua pretensão. É manifesta a ligação entre a descredibilização da declaração e o interesse no desfecho, sendo mais credíveis as declarações feitas em detrimento dos próprios declarantes. São estas considerações que estão na base do regime legal sobre a declaração confessória e o seu valor probatório ${ }^{107}$. As declarações dos interessados que a LUF agora refere, na medida em que sejam favoráveis

106 Cfr. LEBRE DE FREITAS (2013), p. 276.

107 Cfr. VAZ SERrA, pp. 154 e ss e 219 e ss. Sobre a declaração confessória extrajudicial e respetivo valor probatório, cfr. LEBRE DE FREITAS (2013), pp. 261 e 276. 
à sua pretensão, estarão sujeitas ao confronto com a demais prova e ao princípio da livre apreciação da prova. Ora, estes documentos serão elementos destinados à instrução de procedimentos em que os interessados pretendem beneficiar dos efeitos previstos nesta lei, por exemplo, em face dos herdeiros do falecido (artigo $2020 .^{\circ}$ do CC), do senhorio (artigos $1105 . .^{\circ}$ e $1106 .{ }^{\circ}$ do CC), das entidades responsáveis pelo pagamento das prestações por morte (art. 6. $\left..^{\circ}, .^{\circ} 2\right)$. Apenas se poderá considerar como confissão extrajudicial, reconhecendo-lhe força probatória plena, quando a declaração confessória for feita por escrito à parte favorecida pela realidade do facto confessado, isto é, quando diga respeito a factos desfavoráveis ao declarante, em concreto idóneos a produzir consequências vantajosas para o declaratário ${ }^{108}$.

A demonstração dos factos pressupostos pela relevância jurídica da união de facto foi facilitada no caso do acesso às prestações do Estado no caso de morte. Do n..$^{\circ}$ do artigo $6 .^{\circ}$ da LUF parece resultar talvez a função mais importante que se pretendeu atribuir aos elementos probatórios preconstituídos que acabei de analisar. Ao prever que a entidade responsável pelo pagamento das prestações previstas nas alíneas $e$ ), $f$ ) e $g$ ) do artigo $3 .^{\circ}$, caso entenda existirem "fundadas dúvidas sobre a existência da união de facto, deve promover a competente ação judicial com vista à sua comprovação", a LUF pressupõe que tais prestações não serão requeridas por meio de uma ação judicial e que o requerimento será acompanhado com documentos destinados a comprovar a situação que origina o benefício social. Como se viu atrás, a união de facto não tem de ser provada por meio de ação judicial nem a sua dissolução por vontade de um dos membros tem de ser judicialmente declarada (artigo 8. n. ${ }^{\circ} 2$ da LUF); no entanto, quando se pretendam fazer valer direitos

108 Cfr. os artigos $352 .^{\circ}, 355 .^{\circ}$, n. $^{\circ}$, e $358 .^{\circ}$, n.. ${ }^{\circ}$ 2. Cfr. LEBRE DE FreitAS (2013), p. 261. 
que dependam dela, tem de haver uma ação judicial destinada a proferir a declaração judicial de que existiu uma união de facto e que esta se dissolveu (bem como a reconhecer os direitos que se pretendem fazer valer, se for esse o caso) (artigo $8 .^{\circ}$, n. $^{\circ}$ s 2 e 3 ). Tratando-se do acesso a prestações sociais por morte, excecionalmente, o procedimento será meramente documental. Contudo, na medida em que tais documentos não demonstram a realidade de todos os factos pressupostos pelo benefício, a entidade responsável, tendo "fundadas dúvidas sobre a existência da união de facto", deve propor a competente ação judicial. A meu ver tratar-se-á de uma ação de simples apreciação negativa, pelo que, embora o ónus da propositura da ação incumba à entidade responsável, competirá ao membro sobrevivo da união de facto comprovar os factos constitutivos do seu direito, nos termos do artigo $343 .^{\circ}$, n. ${ }^{\circ} 1$, do CC.

O disposto no n. 3 do art. $6 .^{\circ}$ suscita-me maiores dúvidas. Nos termos do n..$^{\circ} 1$ do artigo $6 .^{\circ}$, para aceder às prestações por morte a que tem direito, o membro sobrevivo da união de facto terá de requerer tal benefício à entidade responsável, instruindo o processo com os documentos necessários para provar a situação pressuposta pelo mesmo; de acordo com o . $^{\circ} 2$, se a entidade responsável tiver dúvidas fundadas sobre a existência da união de facto, deve promover a ação judicial destinada à sua comprovação; de acordo com o n. ${ }^{\circ} 3$, "Exceptuam-se do previsto no . $^{\circ} 2$ as situações em que a união de facto tenha durado pelo menos dois anos após o decurso do prazo estipulado no.$^{\circ} 2$ do artigo 1. ". O que significa "excetuam-se do previsto no n. ${ }^{2}$ "? Será que a entidade responsável não pode entender que existem fundadas dúvidas? Ou que não deve promover a competente ação judicial com vista à sua comprovação? Parece que se tratará desta última hipótese, o que apenas terá importância no caso das entidades de natureza pública. Por outro lado, não se percebe a relevância particular atribuída a uma união de facto com duração superior a quatro anos. 


\subsection{O reconhecimento de uma forma de "economia doméstica" comum}

Mais uma vez, não ficaram consagradas na lei quaisquer soluções para os problemas que PEREIRA COELHO tem referido quanto à responsabilidade solidária por dívidas contraídas para acorrer aos encargos da vida do lar e à divisão do património adquirido durante a relação, muito embora apenas para as uniões de facto entre pessoas de sexo diferente ${ }^{109}$. As sugestões de PEREIRA COElHo e as decisões dos Tribunais enfrentam todavia duas objeções importantes. Por um lado, tratar-se-á de "advinhação judiciária", isto é, da construção de uma teoria a posteriori para justificar aquilo em que os membros da união de facto nem sequer pensaram; ou de "contorsões" do Direito comum, muitas vezes insatisfatórias ${ }^{110}$. Por outro lado, se as pessoas vivem em união de facto porque não querem casar, "seria uma violência impor-lhes o estatuto matrimonial, que elas deliberadamente rejeitaram"11.

No entanto, não pode deixar de se reconhecer que serão precisamente os elementos caracterizadores da comunhão de vida patrimonial entre os unidos de facto que a aproximarão da comunhão de vida conjugal: o esforço conjunto, a contribuição para as despesas comuns e a colaboração na vida quotidiana e profissional geram expetativas de participação no património adquirido a merecer uma disciplina reguladora dos conflitos eventualmente suscitados por ocasião da ruptura112.

Apesar de tudo, importa salientar que algumas das normas aprovadas pressupõem o reconhecimento da existência de alguma forma

109 GUILHERME DE OLIVEIRA explica, as normas que previam soluções para estes problemas acabaram por não constar da Lei, na sequência de veto do Presidente da República cfr. (2010), pp. 150-152).

110 XAVIER, Rita Lobo (2000), p. 475, em nota.

111 Curso... (2008), p. 58.

112 XAVIER, Rita Lobo, ob. e loc. cit.. 
de "economia doméstica" comum, tal como Pereira COElHo tem feito com referência às uniões de facto heterossexuais.

Em primeiro lugar, atribuiu-se ao membro sobrevivo da união de facto o direito a prestações sociais, "independentemente da necessidade de alimentos" (artigo $6 .^{\circ}$, n. ${ }^{\circ} 1$, da LUF). Para ter acesso às prestações sociais, o membro sobrevivo da união de facto tinha de demonstrar não existirem familiares obrigados a prestar-lhe alimentos que o pudessem fazer nem, as suas necessidades poderem ser satisfeitas à custa da herança do falecido. O texto legal encontrava a sua justificação no facto de os membros da união de facto não se terem vinculado a um dever de assistência recíproco, como acontece no casamento, pelo que não se poderia depreender da morte de um deles uma diminuição dos rendimentos disponíveis'113. A atual redação do artigo $6 .^{\circ},{ }^{\circ}{ }^{\circ} 1$ da LUF reconhece assim a "assistência informal" que decorre da partilha de recursos que envolve a vida em comum ${ }^{114}$.

Idêntica observação se pode fazer a propósito da atual versão do artigo $20200^{\circ}$ do CC. O artigo $20200^{\circ}$ reconhecia ao membro sobrevivo da união de facto o direito a exigir alimentos da herança do falecido com quem vivesse há mais de dois anos, se este não fosse casado ou, sendo casado, estivesse separado de pessoas e bens, caso não pudesse obtê-los do cônjuge ou ex-cônjuge, dos descendentes, dos ascendentes ou dos irmãos. Torna-se agora claro que os pressupostos da relevância jurídica da união de facto reportam-se à LUF, mas sobretudo que o direito do membro sobrevivo não depende da demonstração de que não pode obter alimentos dos seus familiares enunciados no artigo $2009 .^{\circ}$ do CC, cabendo em primeira linha a

113 XAVIER, Rita Lobo (2007), p. 20. Sustentei que a diminuição de rendimentos do sobrevivo poderia ser demonstrada pela prova de que no caso concreto a união de facto envolvia uma solidariedade patrimonial semelhante à que se estabelece entre os cônjuges (p. 23).

114 OLIVEIRA, Guilherme de (2010) p. 148. 
obrigação alimentar aos herdeiros do falecido, obviamente na medida das forças da herança ${ }^{115}$.

A atual redação da norma do artigo $2019 .^{\circ}$ do CC, determinando a cessação da obrigação alimentar do ex-cônjuge se o alimentando "iniciar união de facto", corresponde às sugestões formuladas por PEREIRA COElHo, que considerou justificada uma solução neste sentido. GUILHERME DE OLIVEIRA fundamenta a nova redação no facto de a vida em comum supor uma partilha de recursos, o que envolve uma "assistência informal" e justifica que faça cessar prestações anteriores baseadas num casamento dissolvido" 116 . Na verdade, compreende-se o sentido da alteração, muito embora não possa deixar de se apontar algumas dificuldades à solução que ficou consagrada. Se o membro da união de facto credor da prestação de alimentos não se conformar com o facto de o seu ex-cônjuge deixar de pagar tal prestação, caberá a este último, na ação judicial eventualmente proposta, alegar e provar os factos extintivos da sua obrigação. Sendo a união de facto invocada por terceiro com a finalidade de produzir efeitos desfavoráveis a um dos membros daquela relação, parece que não será de exigir a verificação de todos os pressupostos necessários para a sua relevância jurídica, como se salientou atrás. O uso da expressão "início" da união de facto suportará também a interpretação no sentido de que não será necessário comprovar que tal relação dura há mais de dois anos. Contudo, repare-se que, sendo muito difícil a demonstração da existência de uma união de facto por parte de terceiros, o facto de se tratar de uma relação que pode dissolver-se a qualquer momento aumenta a sua dificuldade. Em qualquer altura pode o ex-cônjuge ver "renascida" a sua obrigação alimentar, podendo tal ocorrer mesmo no decurso da ação em que está a tentar comprovar

115 Ob. cit. p. 149.

116 Ob. cit., p. 149. 
a extinção daquela obrigação ${ }^{117}$. Nesta medida, poderá continuar a afirmar-se que, neste aspeto, a união de facto é favorecida em relação ao casamento, podendo as pessoas ser dissuadidas de se casarem para tentarem não perder a pensão de alimentos que recebem do ex-cônjuge ${ }^{118}$. Estas observações têm cabimento no contexto da fixação da obrigação de alimentos a cargo da herança do falecido, na medida em que o n. 3 do artigo $2020 .^{\circ}$ considera aplicável a esta situação o disposto no artigo $2019 .^{\circ}$ quanto à cessação da obrigação alimentar.

Finalmente, faço apenas referência a duas das alterações introduzidas no artigo $5 .^{\circ}$, salientando que atualmente a LUF considera como "núcleo irredutível da proteção conferida ao membro sobrevivo da união de facto" a proteção da casa de morada comum, mesmo contra a vontade do falecido manifestada em testamento ${ }^{119}$. A LUF reconhece agora o direito do membro sobrevivo da união de facto ao uso do recheio da casa de morada comum ${ }^{120}$. Este direito, que não constava da versão anterior da LUF e cuja falta parecia ser sentida por PEREIRA COELHO, na medida em que é um direito reconhecido ao cônjuge sobrevivo, muito embora em termos diferentes, uma vez que este último é herdeiro legitimário, devendo o valor dos direitos de habitação da casa de morada da família e de uso do respetivo recheio ser imputados no respetivo quinhão hereditário, e podendo eventualmente ficar a dever tornas aos co-herdeiros (artigos 2003.

117 Com efeito, o ex-cônjuge aparece na primeira linha dos obrigados a alimentos na ordem indicada no artigo $2009 .{ }^{\circ}$ do CC. Estão vinculados à prestação de alimentos, pela ordem indicada: $a$ ) O cônjuge ou ex-cônjuge.

118 Coelho, Francisco Pereira e Oliveira, Guilherme, Curso de Direito da Família (2008), p. 77.

119 OLIVEIRA, Guilherme de (2010), p. 147. A redação anterior da LUF permitia o afastamento deste direito por disposição testamentária do falecido e daí resultava a sua "fraca proteção" (COELHO, Francisco Pereira e OlIVEIRA, Guilherme, ob. cit. p. 84).

120 A redação do artigo $5 .^{\circ}$ sofreu grandes alterações e a sua análise detalhada excederia os limites impostos pelos objetivos do presente estudo. 
- A e $2003 .^{\circ} \mathrm{B}$ do CC). O membro sobrevivo da união de facto não é herdeiro legal, por isso esta questão apenas se colocará no caso de ser herdeiro testamentário.

\section{Bibliografia}

CANOTIlHO, J. J. Gomes e MOREIRA, Vital, Constituição da República Portuguesa Anotada, Vol. I, 4a Edição. Coimbra Editora, Coimbra, 2007

CID, Nuno de Salter, A comunhão de vida à margem do casamento: entre o facto $e$ o direito. Almedina, Coimbra, 2005

"Sobre o direito de não contrair casamento" in Família, consciência, secularismo e religião. Coimbra Editora, Coimbra, 2010

COELHO, Francisco Manuel Pereira, Curso de Direito da Família, polic.. Coimbra, 1981

Curso de Direito da Família, polic. Coimbra, 1986

"Casamento e família no direito português" in Temas de Direito da Família. Almedina, Coimbra, 1986

"Anotação ao do Acórdão STJ de 05.06.1985" in Revista de Legislação $e$ Jurisprudência, Ano 119. ${ }^{\circ}(1986-1987)$, n. ${ }^{\circ} 3753$ (pp. 372-377) e Ano 120. (19871988), n. ${ }^{\circ} 3756$ (pp. 79-86)

"Casamento e divórcio no ensino de Manuel de Andrade» in AA.VV., Ciclo de Conferências em Homenagem Póstuma ao Professor Doutor Manuel de Andrade. Almedina, Coimbra 2001

COELHO, Francisco Pereira e OlIVEIRA, Guilherme, Curso de Direito da Família, I, Introdução e Direito Matrimonial, $2^{\text {a }}$ Edição. Coimbra Editora, Coimbra, 2001

Curso de Direito da Família, I, Introdução e Direito Matrimonial, $3^{\text {a }}$ Edição. Coimbra Editora, Coimbra, 2003

Curso de Direito da Família, I, Introdução e Direito Matrimonial, $4^{\mathrm{a}}$ Edição. Coimbra Editora, Coimbra, 2008

FREITAS, José Lebre de, A ação declarativa comum, À Luz do Código De Processo Civil de 2013, 3. ${ }^{a}$ Edição. Coimbra Editora, Coimbra, 2013

HÖRSTER, Heinrich, "Há necessidade de legislar em matéria de união de facto?" in AA.VV. , Direito da Família e Política Social-Actas do Congresso Internacional organizado de 1 a 3 de outubro de 1998 pela Faculdade de Direito da Universidade Católica (Porto) ( $\mathrm{M}^{\mathrm{a}}$ Clara Sottomayor e $\mathrm{M}^{\mathrm{a}}$ João Tomé, Coords). Publicações Universidade Católica, Porto, 2001 (65-72)

OLIVEIRA, Guilherme de, "Nota sobre a Lei n. ${ }^{\circ}$ 23/2010 de 30 de Agosto (Alteração à lei da união de facto)", in Lex Familiae, Revista Portuguesa de Direito da Família, Ano 7, n. ${ }^{\circ}$ 14, 2010 (139 - 153).

DIAS, Cristina Araújo «Dissolução da união de facto - Anotação ao Acórdão do TRG de 29.9.2004, Proc. 1289/04", in Cadernos de Direito Privado, n. ${ }^{\circ} 11$, Julho/ Setembro 2005 
"Da Inclusão Constitucional da União de Facto: Nova Relação Familiar", in Estudos em Homenagem ao Prof. Doutor Jorge Miranda, Vol. VI, Faculdade de Direito da Universidade de Lisboa. Coimbra Editora, 2012

"Jurisprudência do Tribunal Europeu dos Direitos do Homem e as novas formas de família", in Revista Jurídica da Universidade Portucalense, n. ${ }^{\circ} 15,2012$

MENDES, João de Castro "Família e casamento", in AA.VV Estudos sobre a Constituição, 1. ${ }^{\circ}$ Volume. Livraria Petrony, Lisboa, 1977

MIRANDA, Jorge e MEDEIROS, Rui, Constituição Portuguesa Anotada, Tomo I, $2^{\text {a }}$ edição. Coimbra Editora, Coimbra, 2010.

NETO, RENATO DE OLIVEIRA, Contrato de Coabitação na União de Facto - Confronto entre o Direito Brasileiro e Português. Almedina, Coimbra, 2006.

PITÃO, António França, União de facto no direito português. A propósito da Lei $n .^{\circ}$ 135/99, de 28/08. Almedina, Coimbra, 2000

Uniões de Facto e Economia Comum (Comentário crítico às Leis $n .{ }^{\circ} \mathrm{S}$ 6/2001 e 7/2001, ambas de 11.05). $3^{\text {a }}$ Edição. Almedina, Coimbra, 2011

SERRA, Adriano Paes da Silva Vaz, Provas (Direito Probatório Material). Lisboa, 1962

SOUSA, Rabindranath Capelo de, O direito geral de personalidade. Coimbra Editora, Coimbra, 1995

XAVIER, Rita Lobo, "Novas sobre a união "more uxorio" em Portugal», in Estudos dedicados ao Professor Mário Júlio de Almeida Costa. Universidade Católica Editora, Lisboa, 2002 (1393-1406)

"O Regime dos Novos Arrendamentos Urbanos e a perspectiva do Direito da Família", in O Direito, Ano 136º, II - III. Lisboa, 2004 (315-334)

"Concentração ou transmissão do direito ao arrendamento habitacional em caso de divórcio ou morte", in Estudos em Homenagem ao Senhor Professor Doutor José de Oliveira Ascensão, Vol. II. Almedina, Coimbra, 2008 (1016-1047)

"Acs. TC n. ${ }^{\circ}$ s 195/2003 e 88/2004 (uniões de facto e pensão de sobrevivência)", (anotação), Justiça Constitucional, 3, 2005 (16-24)

Limites à autonomia privada na disciplina das relações patrimoniais entre os cônjuges. Almedina, Coimbra, 2000 
(Página deixada propositadamente em branco) 